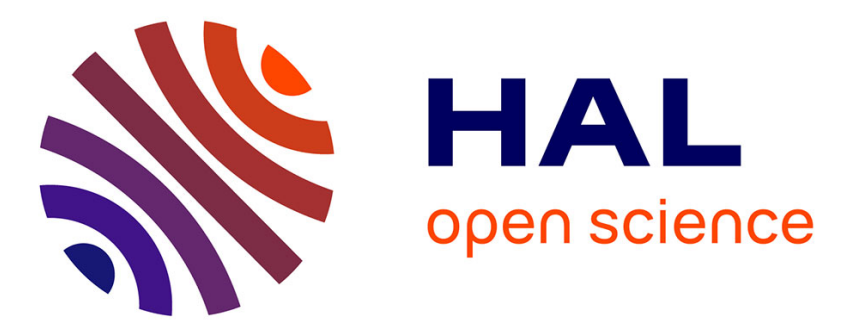

\title{
Application of a sensitive radioimmunoassay for the measurement of growth hormone in gilthead sea bream (Sparus aurata) and other sparid fish
}

Pierre-Yves Le Bail, Brigitte Mourot, Yonathan Zohar, J. Perez-Sanchez

\section{- To cite this version:}

Pierre-Yves Le Bail, Brigitte Mourot, Yonathan Zohar, J. Perez-Sanchez. Application of a sensitive radioimmunoassay for the measurement of growth hormone in gilthead sea bream (Sparus aurata) and other sparid fish. Canadian Journal of Zoology, 1993, 71, pp.1500-1505. 10.1139/z93-211 . hal02714774

\section{HAL Id: hal-02714774 \\ https://hal.inrae.fr/hal-02714774}

Submitted on 1 Jun 2020

HAL is a multi-disciplinary open access archive for the deposit and dissemination of scientific research documents, whether they are published or not. The documents may come from teaching and research institutions in France or abroad, or from public or private research centers.
L'archive ouverte pluridisciplinaire $\mathbf{H A L}$, est destinée au dépôt et à la diffusion de documents scientifiques de niveau recherche, publiés ou non, émanant des établissements d'enseignement et de recherche français ou étrangers, des laboratoires publics ou privés. 


\title{
Application of a sensitive radioimmunoassay for the measurement of growth hormone in gilthead sea bream (Sparus aurata) and other sparid fish
}

\author{
P.-Y. LE BaIl and B. Mourot \\ Laboratoire de Physiologie des Poissons (l'Institut National de la Recherche Agronomique), \\ Campus de Beaulieu, 35042 Rennes CEDEX, France \\ Y. ZOHAR \\ Center of Marine Biotechnology, University of Maryland, 600 East Lombard Street, Baltimore, MD 21202, U.S.A.
}

AND

J. PÉrez-SÁnchez

Instituto de Acuicultura de Torre de la Sal (Consejo Superior de Investigation Cientificas), 12595 Torre de la Sal, Castellón, Spain

Received August 14, 1992

Accepted February 25, 1993

\begin{abstract}
Le Bail, P.-Y., Mourot, B., Zohar, Y., and Pérez-SÁnchez, J. 1993. Application of a sensitive radioimmunoassay for the measurement of growth hormone in gilthead sea bream (Sparus aurata) and other sparid fish. Can. J. Zool. 71: $1500-1505$.
\end{abstract}

The development of a homologous radioimmunoassay (RIA) for gilthead sea bream growth hormone (sbGH) is described. RIA sensitivity was $0.4 \mathrm{ng} / \mathrm{mL}$, and $\mathrm{ED}_{50}$ was $1.74 \pm 0.05 \mathrm{ng} / \mathrm{mL}$. Intra- and inter-assay coefficients of variation were 3.4 and $8.8 \%$, respectively, at $\mathrm{ED}_{50}$ levels. Mammalian growth hormones $(\mathrm{GH})$, carp gonadotropin, chinook salmon gonadotropin, ovine porlactin, and recombinant tilapia prolactin did not show cross-reactivity. Serial dilutions of recombinant trout $\mathrm{GH}$ indicated a low but significant cross-reactivity. The displacement curves for plasma and pituitary homogenates from sparid fish (gilthead sea bream, blacktail, white sea bream, Couch's sea bream, and marmor-brassen) were parallel to that of the sbGH standard. Pituitary homogenates from other perciform fish tested (gaper, grey mullet, red mullet, and sea pike) also showed parallel slopes of inhibition. Pituitary homogenates from common sole, sea scorpion, forked hake, goldfish, rainbow trout, and European eel showed low or negligible cross-reactivity. These results suggest that the GHs of perciform fish have a number of similarities in structure. RIA of sea bream GH can be used to quantify the GH of sparid fish and perciform fish, provided a validation has been carried out.

Le Bail, P.-Y., Mourot, B., Zohar, Y., et Pérez-Sánchez; J. 1993. Application of a sensitive radioimmunoassay for the measurement of growth hormone in gilthead sea bream (Sparus aurata) and other sparid fish. Can. J. Zool. 71 : $1500-1505$.

Ce travail décrit la mise au point d'un dosage radio-immunologique (RIA) de l'hormone de croissance de la Daurade (sbGH). La sensibilité du dosage est de $0,4 \mathrm{ng} / \mathrm{mL}$ avec une $\mathrm{ED}_{50}$ de $1,74 \pm 0,05 \mathrm{ng} / \mathrm{mL}$. Les coefficients de variation intra- et inter-dosages sont respectivement de 3,4 et $8,8 \%$ à la dose de $1,7 \mathrm{ng} / \mathrm{mL}$. Ni les hormones de croissance $(\mathrm{GH})$ de mammifères, ni les gonadotrophines de la Carpe ou du Saumon chinook, ni la prolactine ovine, ni celle du Tilapia ne provoquent de réaction croisée. Les courbes de déplacement obtenues à partir de dilutions sériées de plasma et d'homogénats d'hypophyses de Sparidés (Daurade, Oblade, Sar commun, Pagre, Marbré) sont parallèles à la courbe standard (sbGH). Les homogénats hypophysaires des autres espèces de Perciformes (Serran chevrette, Mulet à grosse tête, Rouget de roche, Brochet de mer) produisent aussi des courbes de déplacement parallèles à la courbe standard. Par contre, les homogénats hypophysaires de la Sole, de la Rascasse rouge, de la Mostelle de roche, du Poisson rouge, de la Truite arc-en-ciel et de l'Anguille européenne, présentent peu ou ne présentent pas de réactivité croisée en fonction du dosage. Ces résultats semblent indiquer que les GH des Perciformes ont de nombreuses similarités de structure. Le dosage RIA de la GH de la Daurade peut donc être utilisé pour quantifier la GH des autres espèces de Sparidés, voire pour quantifier la GH des autres Perciformes si l'on prend soin de le valider pour chaque nouvelle espèce étudiée.

\section{Introduction}

It has been well established that growth hormone (GH) isolated from a variety of species is growth promoting in teleost fish (see Donaldson et al. 1979). Available evidence supports the idea that GH can also be involved in seawater adaptability (Sakamoto et al. 1993), thyroxine conversion (De Luze and LeLoup 1984; MacLatchy and Eales 1990), corticotropin activity (Young 1988), and gonadal growth (Le Gac et al. 1993). Furthermore, it is likely that GH interacts with the immune system, e.g., enhancing the respiratory burst of macrophages and the responsiveness of lymphocytes to mitogens, as has already been demonstrated in mammals (see Kelley 1989). Nevertheless, the mode of GH action and the nature of the mechanisms controlling its secretion have not been fully investigated, mainly because of a scarcity of suitable fish $\mathrm{GH}$ assays.

Homologous radioimmunoassays (RIA) for measuring circulating and pituitary GH levels in tilapia (Farmer et al. 1976), carp (Cook et al. 1983), eel (Kishida and Hirano 1988), and salmonids (Bolton et al. 1986; Wagner and McKeown 1986; Le Bail et al. 1991) are available. A suitable enzyme immunoassay for oncorhynchid GH has also been developed as an alternative to conventional RIA (Farbridge and Leatherland 1991). Yet these immunoassays did not appear to be suitable for obtaining valid measures of immunoreactive $\mathrm{GH}$ in other groups of fishes owing to immunological diversity of $\mathrm{GHs}$ within the superorder Teleostei (Kawauchi et al. 1990).

The sparid family is of increasing interest for aquaculture in most parts of the world. Moreover, these hermaphroditic fish 


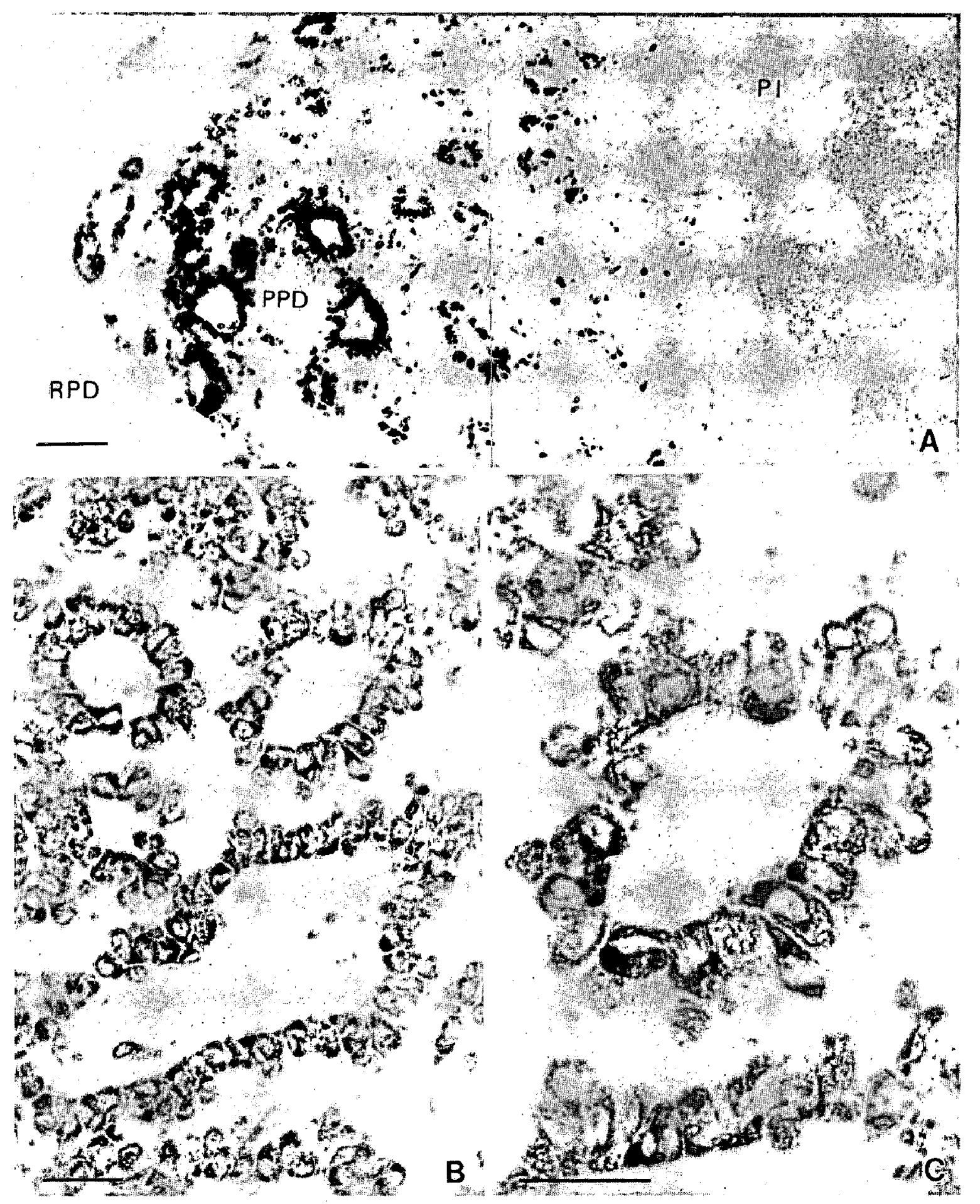

FIG. 1. Light micrographs of a sagittal section of the pituitary gland from a sexually mature male gilthead sea bream. (A) Panoramic view showing immunocytochemical staining of GH cells in the proximal pars distalis (PPD). Scale bar $=100 \mu \mathrm{m}$. Note the absence of immunostaining in the rostral pars distalis (RPD) and pars intermedia (PI). (B and C) Detail of stained secretory cells. Scale bars $=20 \mu \mathrm{m}$.

constitute an original model for investigating the mechanisms involved in sexual dimorphism of growth. The present paper describes the development of a highly sensitive RIA for measuring plasma and pituitary $\mathrm{GH}$ levels in gilthead sea bream (Sparus aurata) and sparid fish in general. The hormone used to raise antiserum and to provide a standard RIA was a gilthead sea bream GH (sbGH) purified from pituitary extracts (G. Pagelson, Y. Zohar, and P.-Y. Le Bail, unpublished data) according to the isolation procedure used for chinook salmon GH (sGH) (Le Bail et al. 1989). The SDS-PAGE electrophoretic characterization of sbGH revealed one major band corresponding to the monomeric form of $\mathrm{sGH}$, which was recognized specifically by anti-chinook salmon growth hormone antibody in immunoblots.

\section{Materials and methods}

Preparation of antisera

Anti-sbGH was obtained from New Zealand white rabbits injected intradermally with $100 \mu \mathrm{g}$ of sbGH every 2 weeks for 4 months; the sbGH was dissolved in $20 \mu \mathrm{L}$ of $10 \mathrm{mM} \mathrm{NaOH}$ diluted to $0.5 \mathrm{~mL}$ with $0.9 \% \mathrm{NaCl}$, and then emulsified with $0.5 \mathrm{~mL}$ of complete Freund's adjuvant.

\section{Immunocytochemistry}

Pituitaries were collected from gilthead sea bream $2+$ years old. GH-producing cells were stained immunocytochemically by means of the unlabelled peroxidase-antiperoxidase method (Quesada et al. 1988), using the above-mentioned anti-sbGH serum diluted 1:2000. Adjacent sections were stained using the Cleveland Ricker Wolfe method to visualize acidophilic cells. 


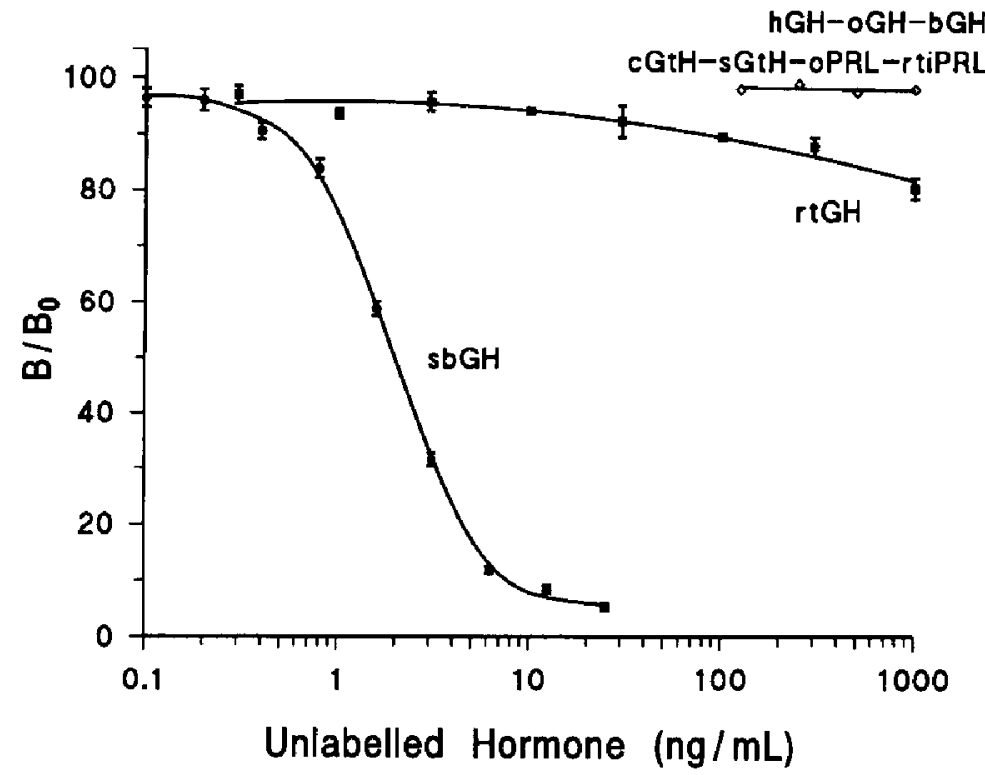

FIG. 2. Dose - response inhibition curves for gilthead sea bream $\mathrm{GH}(\mathrm{sbGH})$, recombinant trout $\mathrm{GH}(\mathrm{rtGH})$, human $\mathrm{GH}(\mathrm{hGH})$, bovine $\mathrm{GH}(\mathrm{bGH})$, ovine $\mathrm{GH}(\mathrm{oGH})$, ovine prolactin (oPRL), recombinant tilapia PRL (rtiPRL), carp GtH (cGtH), and chinook salmon $\mathrm{GtH}(\mathrm{sGtH})$. Each data point represents the mean $\pm \mathrm{SE}$ of quadruplicate determinations.

\section{Iodination}

sbGH was iodinated according to the method used for sGH (Le Bail et al. 1991). Unreacted iodide was separated from the labelled hormone by gel filtration on an AcA 54 column $(60 \times 1 \mathrm{~cm})$ previously saturated with $20 \mathrm{mM}$ Tris $-\mathrm{HCl}$ buffer (pH 7.5) containing $0.05 \%$ $\mathrm{NaN}_{3}$ and $0.5 \%$ bovine serum albumin (BSA). The amount of radioactivity bound by sbGH antibody was high and relatively constant $(90-95 \%)$ in all 15-drop fractions of sbGH peak. Therefore, subsequent separations of the iodide mixture were performed in a more simple and useful Sephadex G-25 column (PD10, Pharmacia). Specific activity (radioactivity/protein content) oscillated around $70 \mu \mathrm{Ci} / \mu \mathrm{g}(1 \mathrm{Ci}=37 \mathrm{GBq})$. ${ }^{125} \mathrm{I}-\mathrm{sbGH}$ was stable for about 2 months when stored in glycerol $(1: 1)$ at $-20^{\circ} \mathrm{C}$.

\section{Source of hormones}

Human GH (hGH), ovine GH (oGH), bovine GH (bGH), and ovine prolactin (oPRL) were supplied by the National Institutes of Health, Bethesda, Maryland. Chinook salmon gonadotropin ( $\mathrm{sGtH}$ ) and carp gonadotropin $(\mathrm{cGtH})$ were generously provided by Dr. B. Breton (I'Institut National de la Recherche Agronomique, Rennes, France). Recombinant tilapia prolactin-I (rtiPRL) and recombinant trout GH (rtGH) were generously supplied by Dr. F. Rentier-Delrue and Dr. J. Smal, respectively (Eurogentec, Liège, Belgium).

\section{Source of plasma and pituitaries}

Black-tail (Oblada melanura), white sea bream (Diplodus sargus), Couch's sea bream (Pagrus pagrus), marmor-brassen (Lithognatus mormyrus), gaper (Serranus cabrilla), red mullet (Mullus surmuletus), grey mullet (Mugil cephalus), sea pike (Sphyraena sphyraena), sea scorpion (Scorpaena scrofa), common sole (Solea vulgaris), and forked hake (Phycis phycis) were captured in the Spanish Levant Coast. Approximately 6-7 h following capture, pituitaries were removed and homogenized in the RIA assay buffer. The homogenates were centrifuged at $2000 \times \mathrm{g}$ for $10 \mathrm{~min}$ at $4^{\circ} \mathrm{C}$, and the supernatant was kept frozen at $-20^{\circ} \mathrm{C}$ until assayed. Blood was taken from the caudal vessels, and plasma was immediately removed by centrifugation at $3000 \times g$ for $30 \mathrm{~min}$ at $4{ }^{\circ} \mathrm{C}$ and kept frozen until assayed. Blood and pituitaries from gilthead sea bream, goldfish (Carassius auratus), rainbow trout, and European eel (Anguilla anguilla) were obtained from fish reared in our facilities, using the same procedures.

\section{RIA procedure}

RIA was performed using a double-antibody method under disequilibrium conditions as previously described for sGH RIA (Le Bail et al. 1991). Plasma and pituitary homogenates were diluted in $50 \mathrm{mM}$ Tris - $\mathrm{HCl}$ assay buffer (pH 7.5) containing $10 \mathrm{mM} \mathrm{MgCl}_{2}$ $\left(\mathrm{H}_{2} \mathrm{O}\right), 0.05 \% \mathrm{NaN}_{3}, 0.1 \%$ Triton $\mathrm{X}-100$, and $1 \%$ BSA. One hundred millilitres of rabbit anti-sbGH serum (diluted 1:20000 in assay buffer containing $0.5 \%$ normal rabbit serum) was added to $100-\mu \mathrm{L}$ volumes of standard and unknown samples. After $24 \mathrm{~h}$ incubation at room temperature, $100 \mu \mathrm{L}$ of labelled sbGH (12000$15000 \mathrm{cpm}$ ) was added to each tube and incubation continued for $24 \mathrm{~h}$. Precipitation of the antibody-bound hormone was made by adding $100 \mu \mathrm{L}$ of diluted (1:5) serum of sheep anti-rabbit gamma globulin in $25 \mathrm{mM}$ Tris $-\mathrm{HCl}$ buffer (pH 7.5) containing $5 \mathrm{mM}$ $\mathrm{MgCl}_{2}, 0.025 \% \mathrm{NaN}_{3}$, and $7.5 \%$ polyethylene glycol. Incubation was prolonged to $24 \mathrm{~h}$ at room temperature, then the tubes were centrifuged for $45 \mathrm{~min}$ at $3000 \times g$, the supernatant was decanted, and the radioactivity in the bound fraction was determined in a Packard gamma counter. Nonspecific binding was up to $3 \%$ of total radioactivity added to each tube. Plasma components did not cause any appreciable effect on nonspecific binding. The radioactivity specifically bound by the antibody in the absence of unlabelled sbGH $\left(B_{0} / T\right)$ ranged between 25 and $30 \%$ of ${ }^{125} \mathrm{I}$-sbGH added.

\section{Statistics}

$B / B_{0}$ values (the radioactivity bound in the presence of various amounts of cold sbGH expressed as a percentage of the radioactivity specifically bound in the absence of unlabelled sbGH) derived from serial dilutions of hormones, plasma, and pituitary homogenates were converted to logits; the slopes were calculated for each set of points and then compared with the sbGH standard curve by analysis of covariance. The slopes were considered to be significantly different if $p<0.05$.

\section{Results}

Figure 1 shows a sagittal section of a gilthead sea bream pituitary stained with the antiserum used in the RIA. The antiserum immunostained only acidophilic cells of the proximal pars distalis, which were found isolated in clusters and all around the pars nervosa branches. No staining was seen in the pars intermedia or in the rostral pars distalis.

Figure 2 shows that cGtH, sGtH, oPRL, rtiPRL, oGH, bGH, and hGH preparations did not cross-react in our sbGH RIA. A significant displacement was observed with serial dilutions of rtGH, but only at concentrations 500 -fold those of sbGH. The midrange of the RIA $\left(\mathrm{ED}_{50}\right)$, calculated as the amount of $\mathrm{sbGH}$ that binds $50 \%$ of $B_{0}$, was $1.74 \pm 0.05 \mathrm{ng} / \mathrm{mL}$ (mean \pm SEM, $n=6$ ). The sensitivity of the assay, defined as the smallest amount of antigen distinguished with a $99 \%$ probability from the zero dose $\left(B_{0}\right)$, was $0.4 \mathrm{ng} / \mathrm{mL}$ ( $40 \mathrm{pg}$ per assay tube). The intra-assay coefficients of variation (CV) for three plasma samples $(2.81,1.4$, and $0.7 \mathrm{ng} / \mathrm{mL}$ ) assayed four times in a single assay were $2.01,3.3$, and $3.56 \%$, respectively. The corresponding interassay CVs, determined in three separate assays, were $4.22,8.82$, and $11.6 \%$, respectively. The slope of the regression line (recovered versus added) of sbGH added to $50 \mu \mathrm{L}$ of gilthead sea bream plasma with low immunoreactivity was $1.06\left(r^{2}=0.998\right)$ (data not shown).

Figure 3 illustrates the displacement curves for serial dilutions of brain and pituitaries. Brain homogenates from gilthead sea bream did not cross-react in the sbGH RIA. Pituitary homogenates from sparid fish, including gilthead sea bream, blacktail, white sea bream, Couch's sea bream, and marmorbrassen, gave inhibition slopes that were not significantly different from the sbGH standard. Pituitary homogenates from other perciform fish (gaper, red mullet, grey mullet, and sea pike) also caused a parallel displacement. Pituitary homogenates from common sole (order Pleuronectiformes), sea scorpion (order Scorpaeniformes), and forked hake (order Gadiformes) 


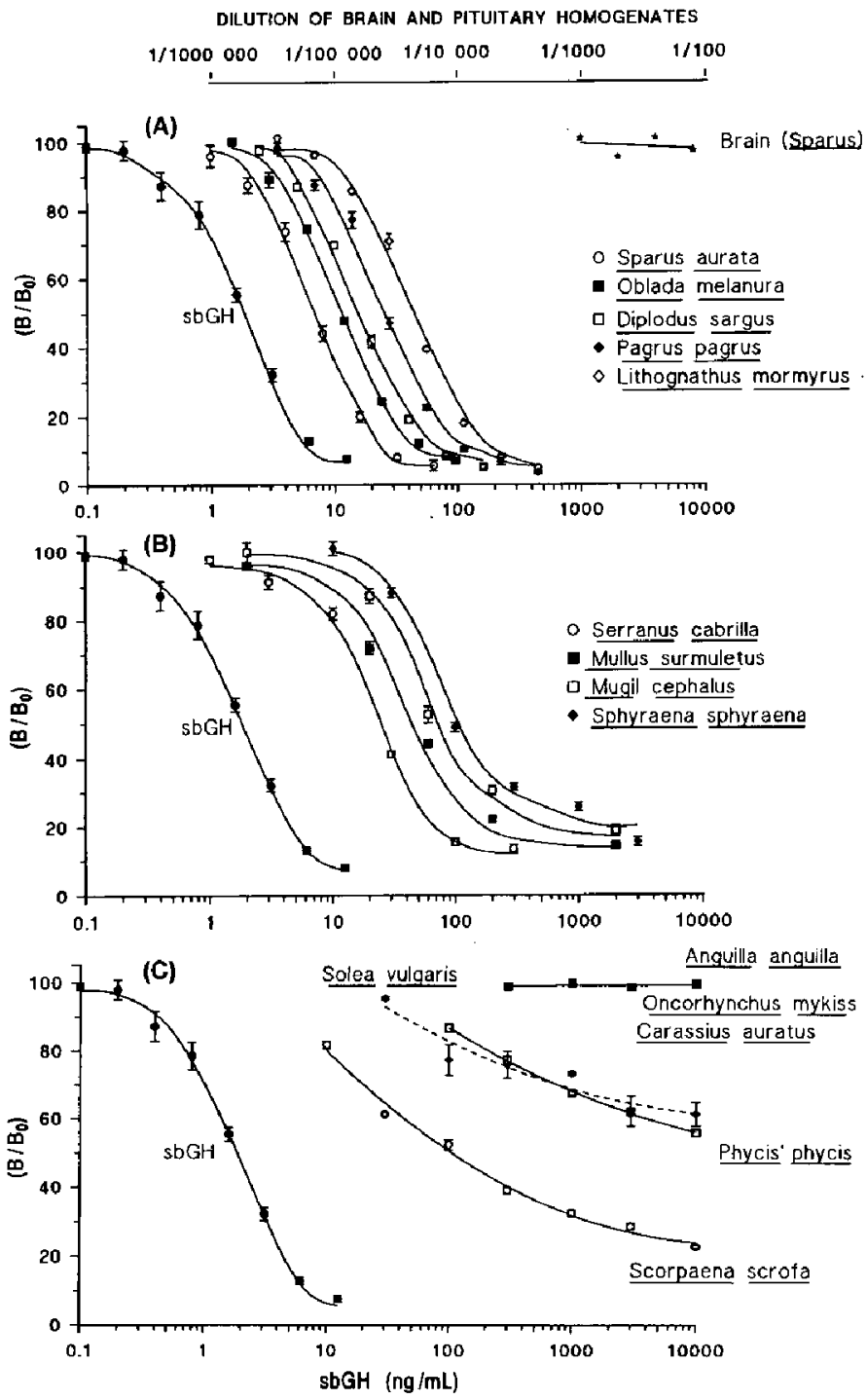

FIG. 3. Dose - response inhibition curves for gilthead sea bream GH (sbGH) and serial dilutions of brain and pituitaries obtained from sparid (A) and nonsparid fish (B, C). Initial dilution of brain and pituitary homogenate: brain and pituitaries from $1 \mathrm{~kg}$ of body mass suspended in $1 \mathrm{~mL}$ of assay buffer. Data points represent the mean \pm SEM of quadruplicate determinations.

produced a significant but nonparallel displacement of the antibody-bound labelled sbGH. European eel (order Anguilliformes), trout (order Salmoniformes), and goldfish (order Cypriniformes) pituitary homogenates did not cross-react in the assay system.

Figure 4 shows that a parallel displacement occurred with gilthead sea bream, blacktail, white sea bream, and Couch's sea bream plasma. Parallel displacement was also observed with red mullet and grey mullet plasma, whereas no significant cross-reaction occurred with European eel, trout, goldfish, and common sole plasma.

\section{Discussion}

The RIA developed in the present study appears to be valid for measuring immunoreactive $\mathrm{GH}$ in gilthead sea bream and sparid fish in general. Plasma and pituitary homogenates from five sparid species (gilthead sea bream, blacktail, white sea bream, Couch's sea bream, and marmor-brassen) showed parallel slopes of inhibition and similar potency in the RIA. Using $B_{0} / T$ ranging between 25 and $30 \%$, the assay was sensitive enough to measure immunoreactive $\mathrm{GH}$ in as little as


FIG. 4. Dose - response inhibition curves for gilthead sea bream GH (sbGH) and serial dilutions of plasma from sparid (A) and nonsparid fish (B). Data points represent the mean $\pm S E$ of duplicate or triplicate determinations.

$2-10 \mu \mathrm{L}$ gilthead sea bream plasma. The $\mathrm{ED}_{50}(1.5-2.0 \mathrm{ng} /$ $\mathrm{mL}$ ) was comparable to that measured for tilapia (Farmer et al. 1976), eel (Kishida and Hirano 1988), and chinook salmon (Le Bail et al. 1991) GH RIAs, and markedly lower than the value reported for carp (Cook et al. 1983) and chum salmon (Bolton et al. 1986; Wagner and McKeown 1986) assays. Furthermore, the precision of the assay was reasonably consistent when intra- and inter-assay $\mathrm{CV}$ s are considered.

Recovery studies suggest that plasma components did not affect the sbGH RIA results. This contrasts with the recognized interference of plasma GH-binding proteins (GH-BPs) in GH radioreceptor assays (RRA) (Mannor et al. 1988). The occurrence of GH-BPs remains unclear in fish species, though Niu (1991) has recently found that trout serum proteins bind humans GHs but not salmonid GH. In any case, the binding affinities of GH-BPs appear to be lower than that of GH RIA antibodies (Baumann et al. 1986; Baumann and Shaw 1990). Therefore, any GH associated with GH-BPs will tend to dissociate and combine with their antibodies during RIA incubation, providing suitable immunoassay measures (Jan et al. 1991).

Pituitary hormones from sparid fish are not currently available for testing in GH assays. Yet it is of considerable significance that sbGH RIA did not cross-react with oPRL, rtiPRL, cGtH, sGtH, nor with oGH, bGH, or hGH. A low but significant cross-reactivity was indicated with $\mathrm{rtGH}$, in a similar way 


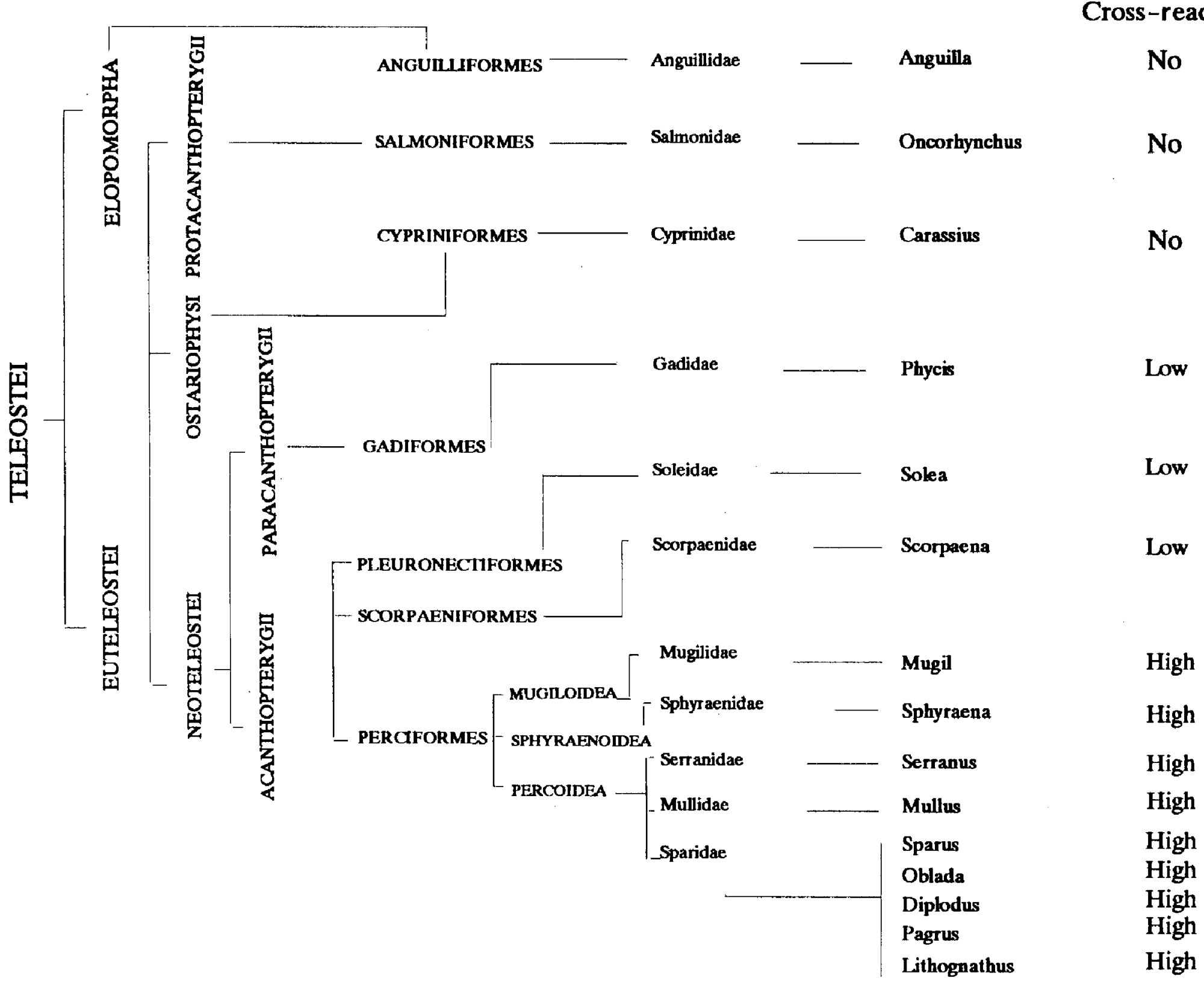

FIG. 5. Diagrammatic representation of sbGH RIA cross-reactivity within the superorder Teleostei.

to that reported for sbGH in an sGH RIA (Le Bail et al. 1991). Conversely, sbGH and sGH have a similar potency to compete for liver GH-binding sites in a trout GH RRA (Yao et al. 1991), as reported for eel and salmonid GHs in an eel GH RRA (Hirano 1991). These results suggest that the receptor binding site of GH is more conserved than the other regions of the molecule.

Sparid GHs (Momota et al. 1988a; Funkenstein et al. 1991) most resemble $(85 \%)$ the GHs of the yellowtail (Watakiki et al. 1988), tuna (Sato et al. 1988), bonito (Noso et al. 1988), and tilapia (Yamaguchi et al. 1991), which are in the order Perciformes. The sequence identity diminished to $65 \%$ with GHs from Japanese flounder (order Pleuronectiformes) (Momota et al. 1988b) and salmonid fish (order Salmoniformes) (Agellon and Chen 1986; Kawauchi et al. 1986; Nicoll et al. 1987). Moreover, the homology of sparid GHs with Japanese eel (order Anguilliformes) GH is as low (40\%) as with GHs from species in other vertebrate classes (Saito et al. 1988; Yamaguchi et al. 1987). This may explain why cross-reactivity with eel and tilapia pituitary homogenates is negligible in salmonid GH RIAs (Bolton et al. 1986; Le Bail et al. 1991). Kishida and Hirano (1988) also showed that the cross-reactivity of tilapia and salmonid pituitary homogenates is insignificant in eel
GH RIAs. Similarly, we observed that the cross-reactivity of pituitary homogenates from eel and goldfish is not appreciable in the sbGH RIA. However, pituitary homogenates from common sole (order Pleuronectiformes), sea scorpion (order Scorpaeniformes), and forked hake (order Gadiformes) caused significant cross-reactivity. Moreover, parallel slopes of inhibition were found with gaper, grey mullet, red mullet, and sea pike, which, with sparid fish, are in the order Perciformes. Thus, a cross-reactivity pattern in accordance with taxonomic classification (see Nadal 1987) emerges from our results (Fig. 5). All this, together with the observation that immunostained pituitary cells are similar in location and structural appearance to putative gilthead sea bream GH cells, previously characterized by Quesada et al. (1988) using tilapiaGH antiserum, supports the view that our RIA is specific for $\mathrm{sbGH}$, and the cross-reactivity of sbGH antiserum with other pituitary hormones is, at most, of a minor nature.

In conclusion, these findings suggest that the present RIA is suitable for the measurement of pituitary and circulating GH levels in gilthead sea bream and sparid fish in general and could be extended to other perciform fish provided a validation has been carried out. Its use will facilitate future research on the physiological action of GH in these marine fish. 


\section{Acknowledgements}

We are indebted to Dr. F. Ayala (Universidad de Murcia) for his advice on immunocytochemistry. We are grateful to El Grao (Castellón, Spain) fishermen for providing wildcaught specimens. We also thank Drs. B. Breton, F. RentierDelrue, and J. Smal and the National Institutes of Health for supplying fish and mammalian hormones. We thank Dr. D.J. Webb for revising the English.

Agellon, L.B., and Chen, T.T. 1986. Rainbow trout growth hormone: molecular cloning of cDNA and expression in Escherichia coli. DNA, 5: $463-477$.

Baumann, G., and Shaw, M.A. 1990. A second, lower affinity growth hormone-binding protein in human plasma. J. Clin. Endocrinol. Metab. 70: 680-686.

Baumann, G., Stolar, M.W., Amburn, K., Barsano, C.P., and Devries, B.C. 1986. A specific growth hormone-binding protein in human plasma: initial characterization. J. Clin. Endocrinol. Metab. 62: 134-141.

Bolton, J.P., Takahashi, A., Kawauchi, H., Kubota, J., and Hirano, T. 1986. Development and validation of a salmon growth hormone radioimmunoassay. Gen. Comp. Endocrinol. 62: 230238.

Cook, A.F., Wilson, S.W., and Peter, R.E. 1983. Development and validation of a carp growth hormone radioimmunoassay. Gen. Comp. Endocrinol. 50: 335-347.

De Luze, A., and LeLoup, J. 1984. Fish growth hormone enhances peripheral conversion of thyroxine to triiodothyronine in the eel (Anguilla anguilla). Gen. Comp. Endocrinol. 56: 308-312.

Donaldson, E.M., Fagerlund, U.H.M., Higgs, D.A., and McBride, J.R. 1979. Hormonal enhancement of growth. In Fish physiology. Vol. 8. Edited by W.S. Hoar, D.J. Randall, and J.R. Brett. Academic Press, New York. pp. 455-597.

Farbridge, K.J., and Leatherland, J.F. 1991. The development of a noncompetitive enzyme-linked immunosorbent assay for oncorhynchid growth hormone using monoclonal antibodies. Gen. Comp. Endocrinol. 83: $7-17$.

Farmer, S.W., Papkoff, H., Hayashida, T., Bewley, T.A., and Bern, H.A. 1976. Purification and properties of teleost growth hormone. Gen. Comp. Endocrinol. 30: 91-100.

Funkenstein, B., Chen, T.T., Powers, D.A., and Cavari, B. 1991. Cloning and sequencing of the gilthead seabream (Sparus aurata) growth hormone-encoding cDNA. Gene, 103: 243-247.

Hirano, T. 1991. Hepatic receptor assay for homologous growth hormone in eel (Anguilla japonica), Gen. Comp. Endocrinol. 81: $383-390$.

Jan, T., Shaw, M.A., and Baumann, G. 1991. Effects of growth hormone-binding proteins in serum growth hormone measurements. J. Clin. Endocrinol. Metab. 72: 387-391.

Kawauchi, H., Moriyama, S., Yasuda, A., Yamaguchi, K., Shirahata, K., Kubota, J., and Hirano, T. 1986. Isolation and characterization of chum salmon growth hormone. Arch. Biochem. Biophys. 244: $542-552$.

Kawauchi, H., Yasuda, A., and Rand-Weaver, M. 1990. Evolution of prolactin and growth hormone family. In Progress in comparative endocrinology. Edited by A. Epple, C.G. Scanes, and M.H. Stetson. Wiley-Liss, Inc., New York. pp. 47-53.

Kelley, K.W. 1989. Growth hormone, lymphocytes and macrophages. Biochem. Pharmacol. 38: $705-713$.

Kishida, M., and Hirano, T. 1988. Development of radioimmunoassay for eel growth hormone. Nippon Suisan Gakkaishi, 54: $1321-1327$.

Le Bail, P.-Y., Boulard, G., Barrenton, B., and Zygmunt, M. 1989. Purification of chinook salmon (Oncorhynchus tshawytscha) GH for receptor study. Fish Physiol. Biochem. 7: 243-251.

Le Bail, P.-Y., Sumpter, J.P., Carragher, J.F., Mourot, B., Niu, P.D., and Weil, C. 1991. Development and validation of a highly sensitive radioimmunoassay for chinook salmon (Oncorhynchus tshawytscha) growth hormone. Gen. Comp. Endocrinol. 81: $73-85$.

Le Gac, F., Blaise, O., Fostier, A., Le Bail, P.-Y., Loir, M., Mourot, B., and Weil, C. 1993. Growth hormone (GH) and reproduction: a review. Fish Physiol. Biochem. In press.

MacLatchy, D.L., and Eales, J.G. 1990. Growth hormone stimulates hepatic tyroxine $5^{\prime}$-monodeiodinase activity and 3,5,3'-triiodothyronine levels in rainbow trout (Salmo gairdneri). Gen. Comp. Endocrinol. 78: 164-172.

Mannor, D.A., Shaw, M.A., Winer, L.M., and Baumann, G. 1988. Circulating growth hormone-binding proteins inhibit growth hormone $(\mathrm{GH})$ binding to $\mathrm{GH}$ receptors but not "in vivo" $\mathrm{GH}$ action. Am. Res. 36: 870A. (Abstr.)

Momota, H., Kosugi, R., Hiramatsu, H., Ohgai, H., Hara, A., and Shioka, H. 1988a. Nucleotide sequence of cDNA encoding the pregrowth hormone of red sea bream (Pagrus major). Nucleic Acids Res. 16: 1307.

Momota, H., Kosugi, R., Ohgai, H., Hara, A., and Ishioka, H: 1988b. Amino acid sequence of flounder growth hormone deduced from a cDNA sequence. Nucleic Acids Res. 16: 10362.

Nadal, J. 1987. Zoología Cordados. Editorial Reverté, Barcelona. (Revised version of Textbook of zoology: vertebrates. 7th ed.)

Nicoll, C.S., Steiny, S.S., King, D.S., Nishioka, R.S., Mayer, G.L., Eberhardt, N.L., Baxter, J.D., Yamanaka, M.K., Miller, J.A., Seilhamer, J.J., Schilling, J.W., and Johnson, L.K. 1987. The primary structure of coho salmon growth hormone and its cDNA. Gen. Comp. Endocrinol. 68: $387-399$.

Niu, P.-D. 1991. Étude du polymorphisme de la GH chez la truite arc-en-ciel (Oncorhynchus mykiss). Thèse d'université, Rennes I, pp. 90-98.

Noso, T., Yasuda, A., Kawazoe, I., Takehara, H., Takahashi, A., Sakai, K., and Kawauchi, H. 1988. Isolation and characterization of growth hormone from a marine fish, bonito (Katsuwonus pelamis). Int. J. Pept. Protein Res. 32: 579-589.

Quesada, J., Lozano, M.T., Ortega, A., and Agulleiro, B. 1988. Immunocytochemical and ultrastructural characterization of the cell types in the adenohypophysis of Sparus aurata L. (Teleost). Gen. Comp. Endocrinol. 72: 209-225.

Saito, A., Sekine, S., Komatsu, Y., Sato, M., Hirano, T., and Itoh, S. 1988. Molecular cloning of eel growth hormone and its expression in Escherichia coli. Gene, 73: 545-551.

Sakamoto, T., McKormick, S.D., and Hirano, T. 1993. Osmoregulatory actions of growth hormone and its mode of action in salmonids: a review. Fish Physiol. Biochem. In press.

Sato, N., Watanabe, K., Murata, K., Sakaguchi, M., Kariya, U., Kimura, S., Nonaka, M., and Kimura, A. 1988. Molecular cloning and nucleotide sequence of tuna growth hormone cDNA. Biochim. Biophys. Acta, 949: 35-42.

Wagner, G.F., and McKeown, B.A. 1986. Development of a salmon radioimmunoassay. Gen. Comp. Endocrinol. 62: 452-458.

Watakiki, N., Tanaka, M., Masuda, N., Yamanaka, M., Yoneda, Y., and Nakashima, K. 1988. cDNA cloning and primary structure of yellowtail (Seriola quinqueradiata) pregrowth hormone. Gen. Comp. Endocrinol. 70: $401-406$.

Yamaguchi, K., Yasuda, A., Kishida, M., Hirano, T., Sano, H., and Kawauchi, H. 1987. Primary structure of eel (Anguilla japonica) growth hormone. Gen. Comp. Endocrinol. 66: 447-453.

Yamaguchi, K., King, D.S., Specker, J.L., Nishioka, R.S., Hirano, T., and Bern, H.A. 1991. Amino acid sequence of growth hormone isolated from medium of incubated pituitary glands of tilapia (Oreochromis mossambicus). Gen. Comp. Endocrinol. 81: $323-331$.

Yao, K., Niu, P.D., Le Gac, F., and Le Bail, P.-Y. 1991. Presence of GH specific binding sites in rainbow trout (Oncorhynchus mykiss) tissues: characterization of the hepatic receptor. Gen. Comp. Endocrinol. 81: 72-82.

Young, C. 1988. Enhanced response of the interrenal of coho salmon (Oncorhynchus kisutch) to ACTH after growth hormone treatment in vivo and in vitro. Gen. Comp. Endocrinol. 71: 85-92. 